\title{
Challenges and Prospects Facing Trading Entrepreneurial ventures in Buea municipality, Cameroon
}

\author{
Eho Olong Christopher ${ }^{1,}$, Dr J. Merlin Mfondo A. N. ${ }^{2}$ \\ ${ }^{1,2}$ Department of Business and Management Studies, Pan African Institute for Development - West Africa \\ *Corresponding Author: Eho Olong Christopher, Department of Business and Management Studies, \\ Pan African Institute for Development - West Africa
}

\begin{abstract}
There exist an acute want of information on the challenges and prospects for entrepreneurial ventures in many developing countries. This paper therefore seeks to show some light in this sector, by examining the challenges and prospects facing trading entrepreneurial ventures in Cameroon the case of some selected trading enterprises in Buea Municipality. The research was based on three objectives which where: (1)to examine the nature and characteristics of entrepreneurial trading ventures in Buea Municipality,(2) to assess the internal challenges facing these entrepreneurial ventures and lastly, (3) to identify opportunities to enhance these entrepreneurial ventures. To achieve these objectives, the study made use of the descriptive survey design and employed a sample of 115 respondents that were drawn conveniently from the study population. Data was collected principally using a close ended questionnaire. The quantitative data were analysed using descriptive and inferential statistics with the aid of the Statistical Package for Social Science (SPSS) version 21 and Microsoft Excel 2013. The findings showed that, 80\% of the trading entrepreneurs in Buea deal mostly in cosmetic, electronic, fashion etc. These traders possess at least two characteristics of entrepreneurship with small sizes, few numbers of employees, very few number of branches established etc. Also, the Results revealed that, internal challenges like; lack of business plan, strategy, skills, staff, structure, finances, style, system were the most prominent amongst the ventures examined. The findings equally showed that, 57\% of traders would prefer attaining workshops and seminars rather than constitute themselves into group which could help them grows the businesses at a faster rate. $75 \%$ of them also agreed that, taxes levied by the Government are too heavy on them hence preventing their growth. The research therefore recommended that, taxes should be reduced, all businesses should have a plan on how to operate starting from the supplier to the consumer.
\end{abstract}

Keywords: Entrepreneur, Entrepreneurial Venture, Prospects and Challenges

\section{INTRODUCTION}

Every successful entrepreneur has to pictures out the challenges that can possibly affect the business, anticipates the prospective market situations and work to minimize the costs while maximizing the profits. Yet several decades since entrepreneurial ventures were described by Schumpeter, (1947) as agent of development, there still exist acute want of information on the challenges and prospects of entrepreneurial ventures in many developing countries. According to Schumpeter, (1947), entrepreneurial activity lay in the creation of "new combinations" that disrupted the competitive equilibrium of existing markets, products, processes and organizations and drives the economy forward. According to Hitt, Ireland, Sirmon and Trahms (2011) development is achieved thanks the ability of entrepreneurs to identify, assess and exploit business opportunities, create new firms and to renew existing ones. Bruyant and Julien (2001): Hindle and Yenchen (2004); Hisrich et al. (2005) have also added that, entrepreneurship is an important source of wealth for a country.

Entrepreneurship has been characterized by Carland et al. (1984) of possessing two main characteristics of growth and innovation. Here growth reflects the business size, employees/business turn over, number of establishments. According to HIS (2013) small and medium-sized enterprises occupy a significant position in many country's economy. They employ between $35-45 \%$ of the workforce, stimulate growth and help diversify economic activity. Also, they adapt quickly to market changes, creates new job opportunities and drive innovation because of their flexible nature. Gerlach(2014) stated that, entrepreneurs are the creative being whose creative ideas contribute significantly to new products and development that advances the economy. Beside the role played by 
entrepreneurs as a source of wealth for the country, entrepreneurial activities stimulate the economy. Gerlach further explains that, the development of the economy is hinged on entrepreneur's ability to produce new goods and services, resulting to employment creation in the economy. An empirical study conducted in Sweden by Moderat.se, (2014) ascertains that, four out of five jobs are created by entrepreneurs hiring of labour to support start-up, growth and sustainability of the enterprises. Ekonomifakta.se, (2010) compliment this assertion and adds that the corporate landscape in Sweden is dominated by small firms and these small firms are largest employees in the private segment, employing $46 \%$ of the workforce in Sweden.

From the above, it is flawless that, entrepreneurs play a great role in fostering economic growth, supporting communities and even personal growth. In achieving their visions, and the spillover effects, entrepreneurs face a plethora challenges. These challenges according to Shaikh (2010) could be either internal or external. Despite the source, these challenges can negatively impact entrepreneurial success. The external challenges here include political, economic, social, legal, technological ecological, and cultural.

When Burberry noticed the high demand for rainwear, it exploited this chance increasing its production in the market. Also, due to the Japanese and American craving for prestigious exclusive goods export business increased dramatically (Burberry, 2012). Changes in demand and supply are also one great factor that determines success and business performance. Still, on the economic aspect, it is undeniable that, all business and non-business organizations touched the effect of the 2008 economic crisis, which rocked the whole world.

The country's social environment affects the functioning of all business meanwhile it determines the value system of the society. Sociological factors establish the culture of work, labour mobility, work groups, etc., hence, the business action of an enterprise. These factors include cost construction, customs, and conventions, cultural heritage, peoples' view towards wealth and income and scientific methods, seniority respect, the mobility of labour (Pushpraj, 2015). According to him, all these factors have a significant impact on the business. For example, peoples' demand controls the kind of products to be offered for sale; this demand is consequently affected by peoples' attitudes, customs, cultural values, fashion and other related forces. The socio-cultural environment determines the code of manner that is made-up to be followed by the business. The social changes in life also lead to new fashion trends that affect business in any part of the economy especially among youths. For example, fashion (dresses and shoes)-based demands are social based forces that lead to changes or increase in demand and supply. The higher the demand as portrayed in line three demands, the higher the sales level as well as the business act. The lower the demand as shown in line two the lower the level of returns attained.

The lawful environment affects the business owners and its managers greatly (Mühlbacher, Leihs, \&Dahringer, 2006). Legal factors should be flexible, especially law and legal rules that govern business operates. It also includes the exact rulings and courts. Legal provisions may also contribute to more income depending on the environment of operation. For example, Burberry Limited brands a significant portion of its income from licensing, which sums to about $£ 109$ million pounds. This is made possible as portrayed by the graph below because of laws and regulations in its foreign destinations of operations, which allow it to charge licensing fee.

Technological influences affect business concerning technological venture, technological application and the consequence of technology on markets. Therefore, any technological advancement disturbs the business extremely in a country. The type and quality of goods and services to be produced and the type and quality of plant and tackle to be used in a company is determined by the kind of technology employed by that company (Mühlbacher, Leihs, \&Dahringer, 2006). Example, Burberry is extending its web reach so that its customers worldwide can view its brands. For example, the company is targeting the Chinese shoppers directly by initiation a site in China. This is because this target market financial records for 30\% of sales in its London stores (Burberry, 2012).

Ginny (2010) explains that, entrepreneurs need to pay homage to political evolution. In his opinion, the political climate alters inflation, cost of labour interest rates competition and quality of labour. Daisyme (2017) has shown that, political decision can define the type of start-up, their process of creation and success criteria. The political arena of any country impacts the business to a large extent. This political environment is influenced by the political organization, government ideology, nature 
and extent of bureaucracy, the country's political rambling, its foreign policy, defense and military, the country's image and that of its leaders both locally and internationally (Shaikh, 2010). A country's policy that stops the growth of multinationals form of business in the market will automatically reduce the business operations of the company hence limiting its growth. Similarly, government policy that allows licensing that is liberal, liberal exportation and import, the influx of foreign capital and technology, upsets the business operation. Globalization as government policy influences the business. Burberry was able to establish its first foreign exits in Paris, United States, and South America, and distribute its first shipment of raincoat to Japan for of the government's globalization policy. Beside the external factors examined above, entrepreneurs also go through internal challenges as explained by Jurevicius (2013). According to him, McKinsey 7s Model identifies internal features that can be a tread to entrepreneurial ventures. He divided these $7 \mathrm{~S}$ model into soft and hard $\mathrm{S}$. It sought to present an importance on human resources (Soft S), rather than the old mass production tangibles of capital, infrastructure, and equipment, as a key to higher structural performance. The goal of the model is to show how seven elements of the company: Structure, Strategy, Skills, Staff, Style, Systems, and Shared values, can be associated together to achieve efficiency. In a company internal factors, these are the factors that come from within the organization they directly have an impact on the functioning of the organization some of these factors include lack of a standardized legal model for social enterprise is a mutual failing in most less developed countries. Secondly, access to finance is always a major issue given the weak business model and the associated risks. Ask any entrepreneur, and they will say they never have enough funds. And it is true. But it is not because there is a lack of funding; rather there is a lack of appropriate distribution of this finance (Cater \& Chadwick 2008). While big companies have huge pockets, smaller companies find it difficult to fund even small projects this is very common in Cameroon because most businesses are illegally own and as such preventing the business owners from sicking loan from the financial institutions. It is very vital for every business to have a business model, a way for you to generate funds unceasingly and sustainably without conditional on donations from others. When initial out if you rely on donations to field your way through, then the chances of your success are quite little. A company may have enough funds from donations for a while. However, you can never really be sure how much it will have in the future and hence cannot plan anything for the future. So it is often important to keep the financing in mind before starting out because only if we have funds, we can do something worthwhile (Khanka, 2002).

Secondly, lack of skilled Man Force, It is easy for every entrepreneur to find staff. The challenge is to have staff who are talented in what they are expected to do. Talented man force is a concern from most small companies. There is a requirement of dedicated, hardworking, committed people who understand the ideologies (Drucker \& Peter, 1985). There is very little training required working in the enterprise, hence it is important that the entrepreneurs take the initiative to train their staff because only then they can get the best out of them. Many entrepreneurs in less developed countries try to focus on everything in their agenda, what they don't realize is that, if you want to do something useful, they need to have one central agenda and all your work needs to be focused around it.

Also, lack of structure: A structure in an organization is very important for a business to get the best out of its employees. Desai \& Vasant (1998) acknowledged the fact that, it is even more important for an entrepreneur because there is no way to measure the productivity of an employee without a proper structure. Their colleagues can only feel their productivities. Hence to get the best out of any team, it is important to have the proper structure in the team. The hierarchy of order must be maintained in a company as much as it needs to be maintained in any other foundation. And lastly, lack of a plan if an entrepreneur wants to see a change in the growth of his business he/she needs a plan. It is a long drawn out process that does require a certain amount of thinking. Today, the society is, rapidly changing and developing. The challenges that the world face today is the rate of fluctuations that are taking place in our civilization, causing us to find ways to meet up to our changing society's expectations. Mundial (2013) The World Bank's Doing Business Report of 2013 points out that, starting a business in Cameroon is still a difficult process that requires five steps and it takes at least 15 days. Doing Business Report further ranks Cameroon one of the worst countries among those valued regarding enforcing a contract or the burden of tax payments. It is cumbersome for young entrepreneurs to access capital to start their businesses (Muñoz, 2010).According to St-Pierre et al (2015), Infrastructure in Cameroon still needs substantial improvement; poor roads and unreliable electricity constitute major constraints on businesses. Cameroon equally has very low internet dissemination. 
In a period when the Internet defines international competition, Cameroon's rate hovers at a percentage of five. Finally, entrepreneurs may be asked for offering a payoff relating to any part of their business (Foster, 2011). Onugu (2005) contends that, inability and inconsistencies in enforcing laws, bureaucratic interpretation of rules, lack of firm political commitment, lack of accountability, hooliganism, and political muscleman ship, lack of the rule of law, lack of control of corruption are major preventions to entrepreneurial growth in developing countries. Also, inadequate government efforts and deceitful incentives for entrepreneurial development appear to have slowed the process of entrepreneurship development in several developing nations (Chittithaworn, Islam, Keawchana, $\&$ Yusuff, 2011).

The challenges entrepreneur's faces differ from continent to continent and also differ from country to country. These challenges could be internal and/or external challenges and Cameroon is no exception to these challenges. Despite the problems we face in Cameroon, a good number of youths are determined to own businesses and become entrepreneurs Dinga-Nyoh (2005). The creation of the Ministry of Small and Medium Sized Enterprises in Cameroon was to promote this entrepreneur spirit in Cameroon. Groups and institutions like Harambe Cameroon, Computer and Entrepreneurship Development Centre, Douala Cameroon, Youth Action Africa, SIPEC (Sherri's Initiative for Promoting Entrepreneurs in Cameroon) and others are encouraging the growth of entrepreneurs in Cameroon (Yitamben\&Tchinda, 2009).

In many ways, the problems facing contemporary entrepreneurs are the same problems facing any business possessor: developing and marketing products, earning and sustaining profits, and handling employees and projects. In a study carried out by St-Pierre et al (2015) on challenges affecting the growth of Small and Medium Size Enterprises (SME) in Cameroon, he concluded that, businesses in Cameroon are slow, stagnant and collapse after a short period because the business environment does not provide sufficient quantities and qualities of physical, financial, human, information and relationship resources. Other researchers such as Ngorora \& Mago, (2013); Richardson, et al. (2004) concentrated mostly on external challenges affecting enterprises in less developed countries, reason for which this study is concentrating exclusively on the internal challenges of trading entrepreneurs in Buea.

\section{RESEARCH OBJECTIVES}

The main objective of this research is to assess the internal challenges and prospects facing trading entrepreneurs in Buea.

More specifically this work aims to:

- Examine the nature and characteristics of trading entrepreneurs in Buea;

- Investigate the internal challenges facing trading entrepreneurial ventures in Buea;

- Identify opportunities available to enhance trading entrepreneurial ventures in Buea.

\section{RESEARCH QUESTIONS}

This research had as main question; what are the prospects and internal challenges faced by trading entrepreneurs operating in Buea?

More specifically, it will address the following issues:

- What is the nature and characteristics of trading entrepreneurial ventures found in Buea municipality?

- What are the main internal challenges faced by trading entrepreneurs in Buea?

- What are the opportunities that can enhance entrepreneurial development in Buea?

\section{Methodology}

The research adopted the descriptive survey design. A sample of 115trading entrepreneurs were conveniently selected. Data was collected principally using a close ended questionnaire. The quantitative data were analysed using descriptive and inferential statistics with the aid of the Statistical Package for Social Science (SPSS) version 21 and Microsoft Excel 2013. The instrument was validated and its reliability insured using Cronbach Alpha reliability coefficient. 


\section{FINDINGS}

\subsection{Research Question 1: What is the Nature and Characteristics of Entrepreneurial Ventures Found in Buea Municipality?}

According to Coulter (2010) entrepreneurial ventures have growth and profitability as their main characteristics growth could be measured by the number of employee, size (number of branches they are able to open, profit margin, new products etc.)

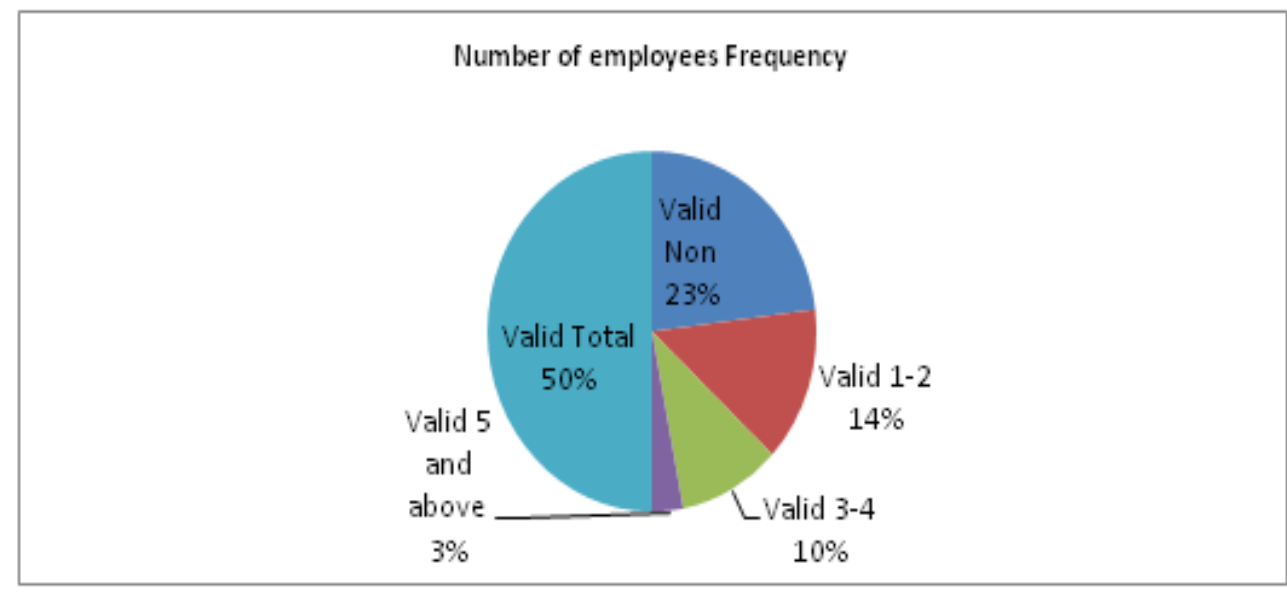

Figure1. The Number of Employees Own By Traders in Buea

Source: Fieldwork (2017)

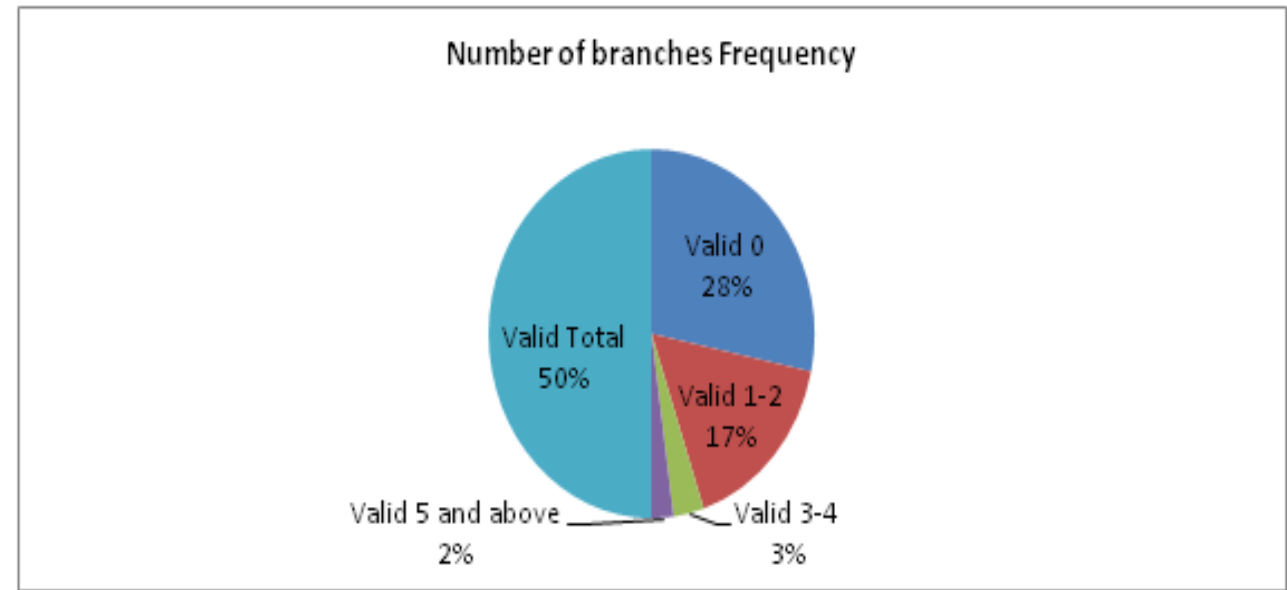

Figure2. Number of branches traders have been able to established in Buea

Source: Fieldwork (2017)

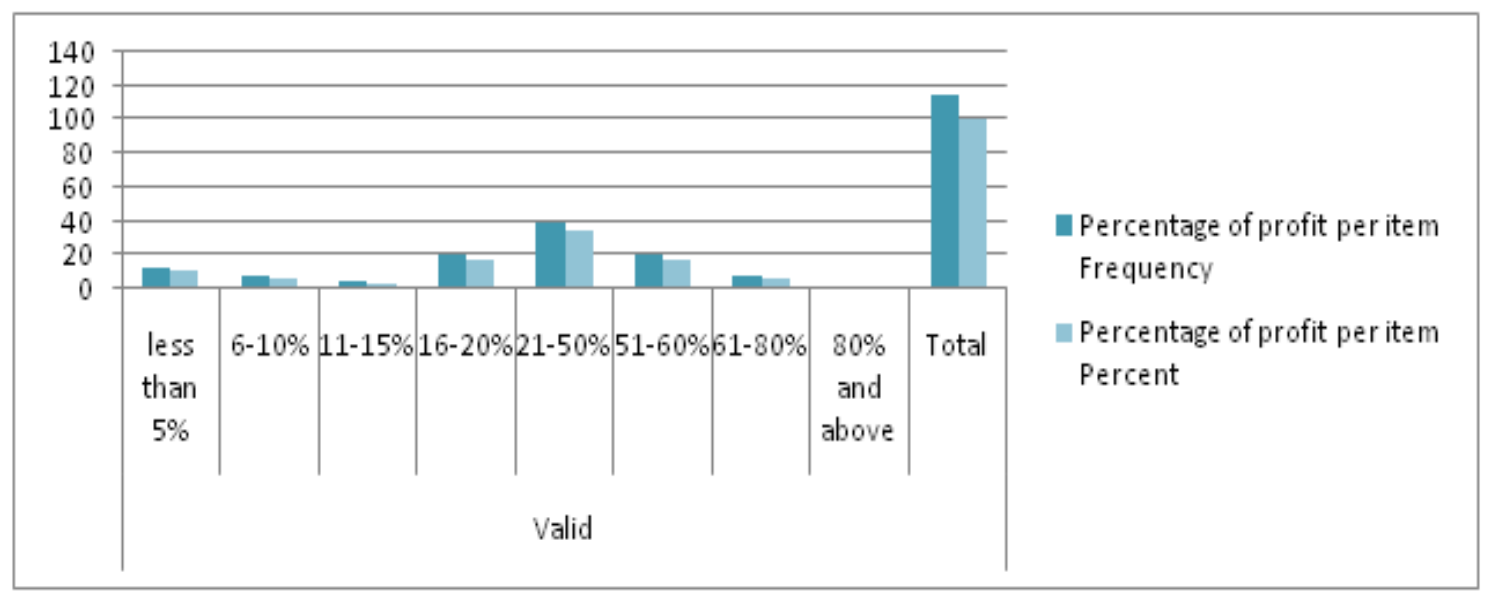

Figure3. Percentage of Profit per Item Sold In trading businesses in Buea

Source: Fieldwork (2017) 


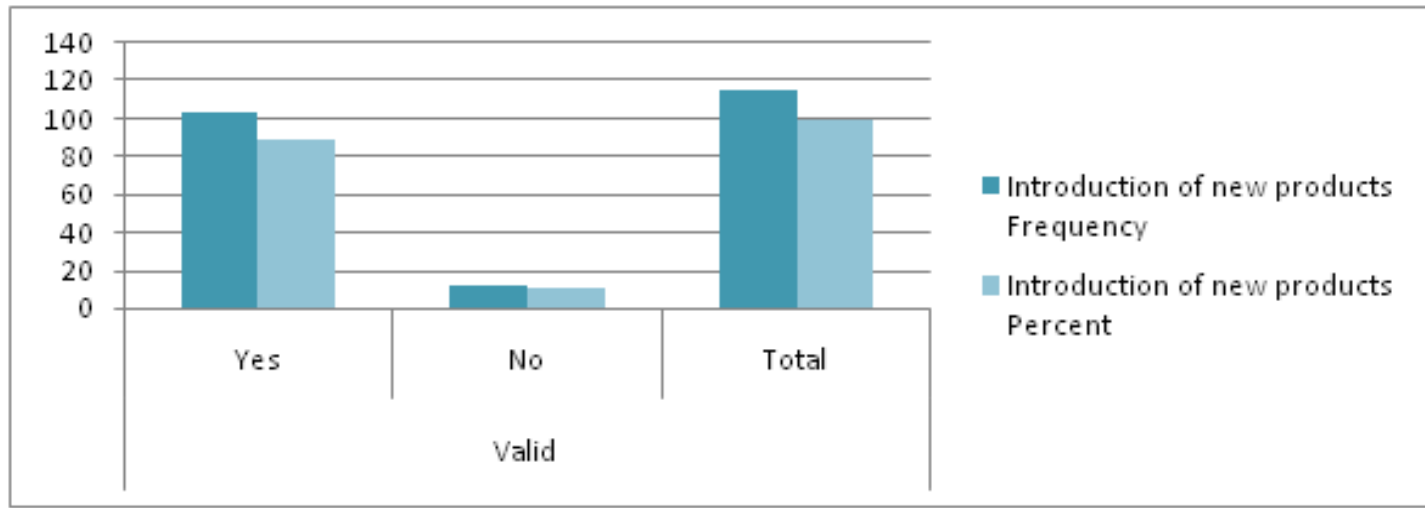

Figure4. Number of traders who have introduced new products in the market different from that which they started with

Source: Fieldwork (2017)

\subsection{Research Question 2: what are the internal challenges facingtrading entrepreneurial ventures in Buea?}

Table1. Internal challenges facing trading entrepreneurs in Buea

\begin{tabular}{|c|c|c|c|c|c|c|}
\hline No & & $\mathbf{S A}$ & $\mathbf{A}$ & $\mathbf{N}$ & $\mathbf{D}$ & SD \\
\hline $\mathrm{C} 1.1$ & Necessity of a business plan & 80.9 & 8.7 & 8.7 & 1.7 & 0 \\
\hline $\mathrm{C} 1.2$ & Internal policies lets to the success of the enterprise/ business & 68.7 & 27.8 & 3.5 & & \\
\hline $\mathrm{C} 2.1$ & Gentleness attacks more customers & 74.8 & 18.3 & 7.0 & & \\
\hline $\mathrm{C} 2.2$ & Have more customers by attaining to customers after sales & 58.3 & 32.2 & 7.0 & 9 & 1.7 \\
\hline $\mathrm{C} 2.3$ & Have more customers if a delivery system is present & 58.0 & 28.7 & 15.7 & 1.7 & 1.7 \\
\hline $\mathrm{C} 2.4$ & $\begin{array}{l}\text { Are the quality of yours goods perceive to be different from those of your } \\
\text { competitors }\end{array}$ & 55.7 & 20.9 & 19.1 & 2.6 & 1.7 \\
\hline $\mathrm{C} 2.5$ & Better shop display improve daily sales & 55.7 & 31.3 & 7.8 & 3.5 & 1.7 \\
\hline $\mathrm{C} 2.6$ & Is it better to sell cheaper goods to expensive goods & 49.6 & 18.3 & 20.9 & 7.0 & 4.3 \\
\hline $\mathrm{C} 2.7$ & Location of your shop gives you an advantage over your competitors & 65.2 & 20.9 & 7.0 & 4.3 & 2.6 \\
\hline $\mathrm{C} 2.8$ & You can make better sales if you move to a different location & 40.0 & 24.3 & 18.3 & 7.0 & 10.4 \\
\hline $\mathrm{C} 2.9$ & My shop is stock with what customers wants & 50.4 & 29.6 & 13.0 & 5.2 & 1.7 \\
\hline $\mathrm{C} 2.10$ & My shop is stock with what I find in the market & 18.3 & 31.3 & 22.6 & 20.9 & 7.0 \\
\hline C3.1 & Necessity of inventory management & 53.0 & 30.4 & 11.3 & 3.5 & 1.7 \\
\hline $\mathrm{C} 3.2$ & Computer software can facilitate inventory management & 31.3 & 43.5 & 17.4 & 5.2 & 2.6 \\
\hline C3.3 & Importance to make customers aware of new products in the market & 33.0 & 24.3 & 27.0 & 9.6 & 6.1 \\
\hline \multicolumn{7}{|l|}{ C3.4 } \\
\hline C3.5 & Using mobile money, checks and credit cards facilitate sales & 45.2 & 16.5 & 10.4 & 16.5 & 11.3 \\
\hline $\mathrm{C} 3.6$ & Giving good on credit cause a negative impact to the business & 53.9 & 19.1 & 8.7 & 10.4 & 7.8 \\
\hline C3.7 & Importance of a website for adverts of goods. & 28.7 & 32.2 & 17.4 & 11.3 & 10.4 \\
\hline C4.1 & $\begin{array}{l}\text { Do you think having a financial department can help keep your day to day } \\
\text { financial statement }\end{array}$ & 28.1 & 21.1 & 34.2 & 7.9 & 8.8 \\
\hline $\mathrm{C} 4.2$ & $\begin{array}{l}\text { Do you thing having a human resource department could help monitor your } \\
\text { employees }\end{array}$ & 15.7 & 30.4 & 28.7 & 7.0 & 18.17 \\
\hline $\mathrm{C} 4.3$ & $\begin{array}{l}\text { Do you think an administrative department could help in developing your } \\
\text { business }\end{array}$ & 33.0 & 14.8 & 27.8 & 9.6 & 14.8 \\
\hline C4.4 & Do you think a marketing department can help to improve sales? & 26.1 & 34.8 & 26.1 & 7.0 & 6.1 \\
\hline $\mathrm{C} 4.5$ & Do you think team work is a good for your business & 28.7 & 30.4 & 30.4 & 4.3 & 6.1 \\
\hline C5.1 & Do you think having internet skills can help improve your business? & 50.4 & 24.3 & 20.9 & 2.6 & 1.7 \\
\hline C5.2 & $\begin{array}{l}\text { Do you think having a good communication skill will be a vital instrument } \\
\text { for the running of your business? }\end{array}$ & 52.2 & 27.8 & 14.8 & 2.6 & 2.6 \\
\hline C6.1 & $\begin{array}{l}\text { Do you think training and mentoring of your staff can help in your } \\
\text { business? }\end{array}$ & 29.6 & 32.2 & 34.8 & 2.6 & 0.9 \\
\hline C6.2 & $\begin{array}{l}\text { Do you think having a database that contains all information about } \\
\text { employee is important? }\end{array}$ & 24.3 & 37.4 & 33.0 & 4.3 & 0.9 \\
\hline C6.3 & $\begin{array}{l}\text { Do you thing leave, gifts, and salary increment act as a motivator to your } \\
\text { employee? }\end{array}$ & 52.2 & 27.8 & 14.8 & 2.6 & 2.6 \\
\hline
\end{tabular}

Source: Field Work (2017) 


\subsection{Research question 3: What are the opportunities to enhance trading entrepreneurial ventures in Buea?}

Table 2:Opportunities to enhancetrading entrepreneurial ventures in Buea

\begin{tabular}{|l|l|l|l|l|l|l|}
\hline & SA & $\mathbf{A}$ & $\mathbf{N}$ & $\mathbf{D}$ & SD \\
\hline D1 & $\begin{array}{l}\text { My Business can do better by attending seminars and workshops on tax } \\
\text { policies are organized }\end{array}$ & 37.5 & 20.0 & 13.3 & 4.3 & 7.0 \\
\hline D2 & My Business can do better by attending seminars and workshops on record keeping & 25.2 & 31.3 & 33.0 & 5.2 & 5.2 \\
\hline D3 & $\begin{array}{l}\text { My Business can do better by attending seminars and workshops on staff } \\
\text { management }\end{array}$ & 32.2 & 27.8 & 28.7 & 6.1 & 5.2 \\
\hline D4 & My business will be more profitable if taxes are reduced & 55.7 & 23.5 & 13.9 & 4.3 & 2.6 \\
\hline D5 & Giving bribe to government officials affect my business & 49.6 & 25.2 & 15.7 & 2.6 & 7.0 \\
\hline D6 & Opportunities for loan can help me expand my business & 43.0 & 24.3 & 15.7 & 6.1 & 0.9 \\
\hline D7 & Interest rate on loan discourages borrowing from banks. & 31.3 & 20.9 & 3.5 & 1.7 \\
\hline D8 & Free business advise can help enhance my business potentials & 35.7 & 24.3 & 30.4 & 4.3 & 3.5 \\
\hline D9 & Do you belong to any group of traders for exchange of ideas & 20.9 & 13.9 & 7.8 \\
\hline D10 & Do you think it is necessary for and expert to be employ to audit your account & & & \\
\hline
\end{tabular}

Source: Field Work (2017)

\section{Discussion OF FINDINGS}

The findings of this research revealed that, from the figure 1 above, most of the trading business in Buea ( $46 \%$ of the respondent) has no employees, while $28 \%$ has between $1-2$ employees, $20 \%$ has between 3-4 and just 6\% has from 5 employees and above. This finding is in line with the finding gotten from Harper (1992) which revealed that, traders and their economic activities fall in the sole proprietorship type of business, meaning that they are generally managed by the owners themselves. According to him, the size of the trading entrepreneurial ventures shows that, these micro and small scale enterprises have less than 10 employees (excluding the entrepreneur in question). This finding is also in accordance with the finding of Fisher and Reuber (2000) who found that, most SMEs are oneperson businesses and the largest employment category is working proprietors.

The figure 2 above showed that, most of the respondent (56\%)has no branches, $34 \%$ has 1-2 branches, $6 \%$ has 3-4 branches and $8 \%$ had from 5 and above branches opened. This finding is in accordance with Harper (1992) which revealed that, most of the SMEs has no branches.

The figure 3 revealed that, most of the respondent 40 (34.8\%) makes $21-50 \%$ of profit per item making their business profitable for them. This finding is in line with the finding gotten from (Advani, 1997) who said that, from the economic perspective, trading entrepreneurial ventures provide a number of benefits.

The figure 4 showed that, most of the respondent 103 agreed that they introduce new products different from the once they started with 12 still sales what they started their establishment. This finding is in line with the finding gotten from (Advani, 1997) who said that, the SMEs divert in different products to adapt with the variations of the environment and it's difficult to find some that are consistent with the same product line they stated the business with without any variation or addition.

The findings from table 1 revealed that, majority of the population accepted the fact that business plan is essential for the operation of their business. Most of them strongly agreed that internal rules and regulations are a vital aspect of business operation, gentleness towards customers could be an aspect of keeping their customers an opportunity for new once. From the questions asked under system, style, structure, skills, and staff most of the respondent $70 \%$ accepted that those factors could create a positive impact to the business if they are implemented. Despite other challenges, the most prominent is that of lack of finances from the statistics run from the respondent view as far of the source of capital is a concern, $53 \%$ start-up capital is from personal savings, only $18 \%$ have startup capital from loans. These findings are in accordance with the findings gotten from (Aftab and Rahim, 1989; Ekpenyong, 1983; Akamiokor, 1983) for who the Problems associated with SMEs and reasons for their failure include: lack of planning, inimical government rules and regulations, poor marketing strategy, lack of technical know-how, and higher interest rates. 
These findings are also in line with the results gotten from (Okezie, Odii, \&Njoku, 2013) who found that, many ventures lack the skills, tools; bribery Corruption, economic rambling, and a lack of wellestablished infrastructure and management. Also, Government political instability, multiple taxes, failure to adapt to changes in the educational sectors of the country by improving its standard, undermining of female entrepreneurial ventures, poor business planning.

Findings from Table 2 revealed that, majority of the traders accepted that attaining seminar and workshops on tax policies, record keeping, staff management will create a positive impact on their business. Most of them strongly agreed that taxes in Cameroon are so high and if reduced their businesses will be more profitable. They also strongly agreed that loans from the banks comes with a lot of interest rate and makes it difficult for them to borrow funds to expand their businesses and also bribe given to government officials slow down the growth of their businesses. Lastly, most of them also agreed that they could do better if they belonged to a group of traders where they could share ideas on how to improve their businesses. These finding are in accordance with the findings gotten from (Honohan\&Bleck, 2007) who found that, better financial assistance is important to address the problem of difficult access to loan. According to Honohan and Beck, African firms' money is an important proportion of their investment with internal funds, about 68 percent. This surveillance highlights lack of financial help to small-scale enterprises.

\section{CONCLUSION}

From the result of the research, the researchers can say that, entrepreneurship isn't a lasting condition. Meaning that an entrepreneur might only exhibit his or her entrepreneurship during a certain period of its life, it only depends on when he is serious about the business. To be considered an entrepreneur the individual would have to keep the entrepreneurial process active. He would have to keep exploiting new opportunities, innovating, and strengthening competition. In this sense the ownership of a business isn't enough to be considered to be an entrepreneur, the type of venture that is started is what matters and that the entrepreneurial characteristics of growth and innovation of the venture continue to be implemented. Despite all the challenges facing trading entrepreneurial ventures in Buea municipality, they should use the opportunities existing to innovate and ensure the growth of their business.

\section{RECOMMENDATIONS}

Due to the challenges faced by trading entrepreneurs in Buea municipality and the impacts that they have on their survival and growth, we propose the following recommendations.

\subsection{To Policy Makers}

It's recommended that, taxes should be reduced at least for the first five years of any entrepreneurial venture to allow it to become stable before starting paying requested taxes.

It is recommended that the Government, through the delegation of small and medium size enterprises should organize training programs to enable the entrepreneurs develop their skills in business management, marketing, inventory management and accountancy in a way to improve their performance.

\subsection{To Trading Entrepreneurs}

It's recommended that, entrepreneurs should draw business plan before they start with their ventures.

It is recommended that the business owners should recruit managers having skills in management to carry out the various activities of their ventures or they should get trained themselves to better managed their ventures, incorporating inventory management.

It's recommended that, entrepreneurs should develop adapted marketing strategies to attract the customers and fidelize them.

It is recommended that entrepreneurs (sole proprietors) should put in place a mechanism of transfer of ownership before death to ensure the survival of the business in their absence.

It is recommended that, the entrepreneurs should solidarize themselves by creating an association on which to debate about their challenges, such that the MFIs should reduce the interest rate and in such a way that each of the members in the association can act as a collateral to one another. 


\subsection{To Financial Institutions}

From some sources, it has never been easy for an entrepreneur to get a loan from a bank or a micro finance. It's therefore recommended that, the microfinance institutions should reduce their documents to facilitate the accusation of loans by the entrepreneurs.

It is recommended that the microfinance institutions should reduce the time period in giving out loans to entrepreneurs to avoid them losing some punctual opportunities for which the loan is going to be used to.

\section{REFERENCES}

[1] Advani,Bickerton, P. Simacek, S. Guglielmi, S. G. (1997), "Investigation of Draping and Its Effects on the Mold Filling Process During Manufacturing of a Compound Curved Composite Part," Composites - Part A: Applied Science and Manufacturing, v 28, n 9-10.

[2] Aftab, k. and Rahim, E (1989)'Barriers' to the growth of informal sector firms: A case study. Journal of Development Studies, 25, 490-507.

[3] Ajami, r. A. (2006). International business: Theory and Practice Ayers.

[4] Akamiokor. G.A, (1983): Financing of small-scale enterprises. Central Bank of Nigeria Bulletin 8(2).

[5] Albrecht, M. (2010). Supply Chain Coordination Mechanisms . springer.

[6] Aluko, N. (2016). the three flows of supply chain.

[7] Anderson, F. F. (1997). "The Seven Principles of Supply Chain Management". suply chain mangement review.

[8] Bank, w. (2003). Managing agricultural development in Africa: Discussion Paper 7. 8297. washington DC: world bank.

[9] Barney, J. (1991). Firm Resources and Sustained Competitive Advantage. Journalof management, 99-120.

[10] Barney, J. B. (1991). Firm resources and sustained competitive advantage. Journal of Management, 17, 99120.

[11] Bashir, M. A. (2008). Reliability and Validity of Qualitative and Operational Research paradigm .

[12] BBC News. (2009, 02 14). Challenges Facing African's Entrepreneurs. Récupéré sur BBC Newa: http://newsvote.bbc.co.uk/go./pr/fr//1/hi/business/6100180.stm

[13] Blaxter, L. H. (2006). How to Research (3rd Edition).

[14] Bloomberg, D. J. (2002). Logistics Cacaoweb.net Drying cocoa beans. ghana.

[15] Bowen, H. R. (1953). Social Responsibility of a Business man. University of Iowa Press.

[16] Bull, I. a. (1993). Towards a theory of entrepreneurship. Journal of Business Venturing, Vol. 8 No. 3, 183195.

[17] cachon, G. (2003). supply chain management; design, coordination, and cooperation. handbooks in operations research and management sciences. Dans cachon, supply chain coordination with contracts (pp. 229-339). De kok: Elsevier.

[18] Cantillon, R. (1755). An essay on economic theory. Mises Institute.

[19] Carland J, Hoy, F., Boulton, W., \& Carland A. (1984, April). Differentiating Entrepreneurs from Small Business Owners - A Conceptualization: Academy of management review. The Academy of Management Review (pre-1986, p. 354.

[20] Cater III, J. J. (2008). Response to Hurricane Katrina: A small business approach. Academy of Strategic Management Journal, , 7, 55 .

[21] Cetinkaya, B. c. (2011). Sustainable Supply Chain Management; prractical ideas for moving towards the best practices.

[22] Chittithaworn, C., Islam, M. A., Keawchana, T., \& Yusuff, D. H. (2011). Factors Affecting Business Success of Small \& Medium Enterprises (SMEs) in Thailand. Asian Social Science.

[23] Coulter, M. (2010). Strategic management in action. Prentice Hall.

[24] CSCSCS. (2017). supply chain definitions. Canada: Canadian supply chain sector council.

[25] Dada, L. A. (2007). "The African export industry: What happened and how can it be revived? Case study on the Cameroonian cocoa sector". Rome: fao.org.

[26] Davidsson, P. (2008). The Entrepreneurship Research Challenge. UK: Edward Elgar Publishing Limited.

[27] Devoto, L. (2015), the three agricultural challenges in supply chain.

[28] Dunphy, D., \& Stace, D. (1988). Transformational and coercive strategies for. Organizational Studies, 1734. 
[29] Edith, L. K. (2015). main risk in agriculture in Cameroon.

[30] Elfving, J., Brännback, M., \& Carsrud, A. (2009). Understanding the Entrepreneurial Mind: Opening the Black Box. heidelberg: Springer.

[31] Elkan, W. (1988). Entrepreneurs, Entrepreneurship in Africa. Research Observers, World Bank.

[32] Essomba, S. P. (2013). "Assessment of Trade Facilitation an Competitiveness of Cameroon's Coffee Sector: Implications for Trade Liberalisation". Altpere.com.

[33] Essomba, S. P. (2013). Challenges and Opportunities Facing African Policymakers in Promoting Sustainable Development Of Cocoa, Coffee And Cashew. Itta.org.

[34] F., I. I., Ulf, J., \& Beverly, W. (2003). A conceptualisation of the opportunities and barriers to e-business development in the smaller firm. Journal of Small Business and Enterprise Development, 336 - 344.

[35] Fishbein, M., \& Ajzen, I. (1975). Belief, attitude, intention and behavior: An introduction to theory and research. Reading, Massachusettes: Addison Wesley.

[36] Gartner, W. (2007). Is there an elephant in entrepreneurship? Blind assumptions in theory development. Entrepreneurship, Vol. 25 No. 4, 229-242.

[37] Gerlach, M. (2014, November 16). The Importance Of Entrepreneurship. Récupéré sur Soceity 3.0: https://society30.com/importance-entrepreneurship/

[38] Görling, S., \& Rehn, A. (2008). Accidental ventures - A materialist reading of opportunity and entrepreneurial potential. Scandinavian journal of management .

[39] Henriksen L, R. S. (2014). "Agro-Food Value Chain Interventions in Asia: A review and analysis of case studies. Working Paper". UNIDO.

[40] Honohan, P., \& Bleck, T. (2007). Making Finance Work for Africa. Washington, D.C: World Bank.

[41] Howard Aldrich, \& Fiol, C. M. (2007). Fools Rush in? The Institutional Context of Industry Creation. Strategic Entrepreneurship Journal, 11-26.

[42] IEduNote. (2017). Importance of Entrepreneurship. Récupéré sur IEduNote: https://iedunote.com/importance-of-entrepreneurship

[43] IFM. (2013). "Decision Support Tools: Porter's Value Chain". cambridge: Institute of Manufacturing (IFM).

[44] IHS, D. (2013). Internationalization-A driver for business performance. DHL HIS.

[45] Imaoka, Z. (2008). "Understand Supply Chain Management through 100 words". kougyou chousakai.

[46] James, A. (2004). Supply chain project management .

[47] Kaplan, R. (2005). How the balanced scorecard complements the McKinsey 7-S model. Strategy \& Leadership, 41 - 46.

[48] Kaplinsky, R. M. (2014). "A Handbook for Value Chain Analysis". IDRC. Retrieved.

[49] Karami, A. (2005). An exploration of the chief executive officers' perception of strategic management process. Corporate Ownership and Control, 62-64.

[50] Khaire, M., \& Wadhwani, R. (2010). Changing Landscapes: The Construction of Meaning and Value in a New Market - Modern Indian Art. Academy of Management Journal 53.6, 1281-1304.

[51] Kozlenkova, i. V. (2015). "The Role of Marketing Channels in Supply Chain Management". journal of retailing, 586-609.

[52] Krueger, N. F., Reilly, M. D., \& A. L. Carsrud. (2000). Competing models of entrepreneurial intentions. Journal of Business Venturing, 411 - 432.

[53] Kula, O. J., \& Field, M. (s.d.). Globalization and the Small Firm: A Value Chain Approach to Economic Growth and Poverty Reduction.

[54] Kumar. (1992). supply contracts and manufacturing decisions. pittsburg: canergie mellon university.

[55] Laven, A. (2007). Marketing reforms in Ghana's cocoa sector: partial reforms, partial benefits. UK: Odi.org.

[56] Li, X. w. (2007). coordinate mechanism of supply chain systems. Dans e. j. research, coordinate mechanism of supply chain systems (pp. 1-16).

[57] Manage, H. (2015, June 20th). 7-S framework. Récupéré sur Manage: www.12manage.com

[58] Manufacturing, i. f. (2013). "Decision Support Tools: Porter's Value Chain". cambridge: IFM.

[59] Marinus. (2004). what is the Theory of Constraints? . university of project management.

[60] McCormick, D. (1999). African Enterprise Clusters and Industrialization: Theory of. Theory and Reality in World Development, 1531-1551.

[61] Michael A. Hitt, R. D. (May 2011). Strategic Entrepreneurship. Creating Value for Individuals, Organizations, and Society, pp. 57-75 . 
[62] Michael, C. (2012). Innovation and entrepreneurship. The Bottom Line , Vol. 25 No. 3, 98-101.

[63] Moustakis, V. (2000). Material Requirement Planning. university of Crete.

[64] Mühlbacher, H., Leihs, H., \& Dahringer, L. (2006). International marketing: A global perspective. Cengage Learning EMEA.

[65] Navis, C., \& Glynn, M. A. (2010). How New Market Categories Emerge: Temporal Dynamics of Legitimacy, Identity, and Entrepreneurship in Satellite Radio, 1990-2005. Administrative Science Quarterly 55.3, 439-471.

[66] Mbabuine, k. a. (2012). Evaluating the supply chain of ghana cocoa from a company point of view . ghana.

[67] Normansyah. (2011). Towards traceability in cocoa - chocolate supply chain. Bergamo: universita de gli studi di bergamo.

[68] Normansyah. (2012). SUSTAINABLE SUPPLY CHAINMANAGEMENT:A CASE STUDY ON COCOA INDUSTRY IN INDONESIA. bergamo: university of bergamo.

[69] Nwccindia. (2015). factory management, logistic, Supply Chain Management. comments blog.

[70] Ogundele, O. J., \& Abiola, J. O. (2012). Entrepreneurship and national development: A proposal for evangelistic agenda. European Scientific Journal, ESJ.

[71] Okezie, A. I., Odii, A., \& Njoku, A. C. (july 2013). Challenges and Prospects of Entrepreneurship in Nigeria. Academic Journal of Interdisciplinary Studies, 25 - 34.

[72] Onugu, B. A. (2005). Small and Medium Enterprises (SMEs) in Nigeria: Problems and Prospects.

[73] Osemeke, M. (2012). Entrepreneurial Development and Interventionist. International Journal of Business and Social Science.

[74] Ovidijus. (2013). RESOURSE BASE VIEW.

[75] Perdomo, J. 1. (2002). material management challenges in an electrical contracting company.

[76] Peter, D. F. (1985). Innovation and entrepreneurship. Haper \& Row.

[77] Peters, T., \& Waterman, R. (1982). In search of excellence. New York: Harper and Row Publishers.

[78] Porter, M. E. (1998). Competitive advantage: creating and sustaining superior performance; with a new introduction. $1 \mathrm{ST}$ free press ed, 978.

[79] Pushpraj A . (2015). The economic factors affecting business environment. Récupéré sur Publish your articles:http://www.publishyourarticles.net/knowledge-hub/business-studies/the-economic-factors affecting - business-environment/941/

[80] PWC. (2012). "Sustainable Business Solutions strategies and services". pwc.com.

[81] Quartey, E. T. (2013). The Role of Parastatal Institutions in the Agricultural Sector: The Case of Ghana Cocoa Board. ghana.

[82] Ragha. (2008). supply chain management flows.

[83] Ravanfar, M. M. (May 2015). Analyzing Organizational Structure based on 7s model of McKinsey. International Journal of Academic Research in Business and Social Sciences, 43 - 44.

[84] Reuters. (2016). Cameroon's 2015/16 cocoa production rises . USA.

[85] Rindova, V., Ferrier, W., \& Wiltbank, R. (2010). Value from gestalt: How sequence of competitive actions create advantage for firms in nascent markets. Strategic Management Journal 31, 1474-1497.

[86] Rothaermel, F. (2012). Strategic Management: Concepts and Cases. MCGRAW-HILL, 5.

[87] Santos, F., \& Eisenhardt, K. (2009). Constructing Markets and Shaping Boundaries: Entrepreneurial Agency in Nascent Fields. Academy of Management Journal 52.4, 643-671.

[88] Schumpeter, J. (1934). The Theory of Economic Development. Cambridge, MA: Harvard University Press.

[89] Schumpeter, J. A. (1947). The creative response in economic history. The journal of economic history.

[90] Shapero, A. (1982). The social dimension of entrepreneurship. Englewood Cliffs: Prentice-Hall.

[91] Sides, R. (2012). sales and operatons planning and ERP.

[92] Simeon, N. K., \& al, e. (September 2012). Entrepreneurship Challenges in Developing Economies: a case of Kenyan Economy. International Journal of Arts and Commerce, 264 - 273.

[93] Stadler, H. (2009). A framework for collaborative planning and state of the art. OR spectrum, 5-30.

[94] Sunil Chopra, P. M. (2007). Supply Chain Management ; strategic, planning and operation. USA: Pearson Prentice Hall.

[95] Syahruddin, N. (2011). Towards traceability in cocoa - chocolate supply chain. bergamo: universita degli studi.

[96] Syahruddin, N. (2011). Towards traceability in cocoa - chocolate supply chain. bergamo: universita degli studi di bergamo. 
[97] Tirole. (1988). the theory of industrial organisation . MIT press.

[98] Tollens, E. \&. (2003). Does market liberalisation jeopardise export quality? Cameroonian cocoa. journal of african economies, V 12, N.3.

[99] United Nations Conference on Trade and Development, . (2007). Report of the Expert Meeting on Increasing the Participation of Developing Countries SMEs in Global Value Chains.

[100]United Nations Office of the Special Adviser on Africa. (January 2008). Small Scale Enterprise Development and FDI in Africa: Challenges and Opportunities.

[101]Venkataraman, S. (Advances in Entrepreneurship, Firms Emergence, and Growth,). The Distinctive Domain of Entrepreneurship Research: An Editor's Perspective. Katz, J., and Brockhaus, R..

[102]Victor, N. (2014). The sustainability of cameroon cocoa economy. Buea.

[103]Weber, K., Heinze, K., \& DeSoucey, M. (2008). "Forage for Thought: Mobilizing Codes in the Movement for Grass-fed Meat and Dairy Products. Administrative Science Quarterly 53.5, 529-567.

[104]Wennekers, S., \& Thurik, R. (1999). Linking entrepreneurship and economic growth. Kluwer Academic Publishers.

[105]Yumkella, K., \& Vinanchiarachi, J. (2003). Leading Issues on Africa's Path to Industrialization: The Role of Support Systems and instruments. Journal of African Economies, 30-40.

[106]Zukbo, N. (2008). problems in purchasing.

\section{AUTHORS' BIOGRAPHY}

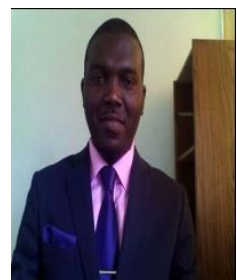

Dr. Mfondo à Ngon Jean Merlin is a University Lecturer, Head of Department of Business and Management Studies at the Pan African Institute for Development West Africa (PAID-WA). Author of some publications in the area of Business and Management, $\mathrm{He}$ is holding a doctorate in Organizations' Management and $\mathrm{He}$ is Consultant for many organizations at both the national and international levels.

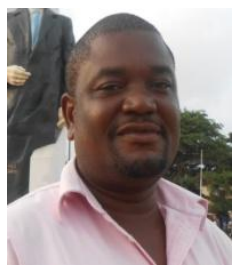

Christopher EhoOlong is a Lecturer, Researcher and Consultant with the Pan African Institute for Development - West Africa (PAID-WA) Buea. His research and teaching explores the different ways in which businesses start-up, grow and are sustained in both the formal an informal sectors of the economy. He left an indelible mark four years ago as Coordinator of the PAID-WA Yaounde Learning Support Centre a glory PAID-WA pride itself of till date. His areas of research include managerial economics, entrepreneurship, project management and international economics. Beside teaching and research, he is a great team leader in entrepreneurship start-up, has held positions of programme coordinator and head of department at the Pan African Institute for Development -West Africa.

Citation: Eho Olong Christopher, Dr J. Merlin Mfondo A. N.. “ Challenges and Prospects Facing Trading Entrepreneurial ventures in Buea municipality, Cameroon " International Journal of Managerial Studies and Research (IJMSR), vol 6, no. 3, 2018, pp. 1-12. doi:http://dx.doi.org/10.20431/2349-0349.0603001.

Copyright: (c) 2018 Authors. This is an open-access article distributed under the terms of the Creative Commons Attribution License, which permits unrestricted use, distribution, and reproduction in any medium, provided the original author and source are credited. 